\title{
The effect of hyperthermia with localised head and neck cooling on neuromuscular function
}

\author{
Ralph Gordon, Neale A Tillin, Jamie Hall, Kelly-Anne Clifford, Christopher J Tyler ${ }^{*}$ \\ From 15th International Conference on Environmental Ergonomics (ICEE XV) \\ Portsmouth, UK. 28 June - 3 July 2015
}

\section{Introduction}

Hyperthermia reduces volitional force production, voluntary muscle activation and agonist-electromyography (EMG) during a sustained maximal voluntary contraction (MVC) [1], [2]. This reduction in neuromuscular function may explain a reduced exercise capacity in the heat. Cooling of the neck has been shown to improve running capacity in the heat [3]; however the mechanism is unknown. The aim of the study was to investigate whether localised cooling of the head and neck during hyperthermia would affect neuromuscular function following $60 \mathrm{~min}$ of cycling in the heat.

\section{Methods}

Fourteen male participants exercised on a cycle ergometer for $60 \mathrm{~min}$ at $50 \% \mathrm{VO}_{2 \max }$ in three experimental conditions; hot $\left(35{ }^{\circ} \mathrm{C}, 50 \% \mathrm{rh}\right.$; HOT), hot with head and neck cooling $\left(35{ }^{\circ} \mathrm{C}, 50 \%\right.$ rh; $\left.\mathrm{HOT}_{\text {cooling }}\right)$ and control $\left(18{ }^{\circ} \mathrm{C}, 50 \%\right.$ rh; CON). Immediately after the cycling bout, participants performed a 120-s sustained isometric MVC of the knee extensors of their dominant limb. Neuromuscular activation was assessed during the MVC at $5,30,90$ and 120 -s by superimposing supra-maximal triplet ( 3 impulses at $100 \mathrm{~Hz}$ ) contractions by electrical stimulation of the femoral nerve, and calculating the central activation ratio (CAR). EMG amplitude (normalised to maximal $\mathrm{M}$-wave) of the 3 superficial quadriceps heads was recorded throughout the MVC. Rectal temperature $\left(\mathrm{T}_{\mathrm{re}}\right)$ was measured throughout each condition.

\section{Results}

$\mathrm{T}_{\text {re }}$ was raised in both the HOT $\left(39.27(0.52){ }^{\circ} \mathrm{C}\right)$ and $\mathrm{HOT}_{\text {cooling }}\left(39.19( \pm 0.56){ }^{\circ} \mathrm{C}\right)$ trials vs $\mathrm{CON}(38.07$ $\left.(0.28)^{\circ} \mathrm{C}\right)$ immediately post cycling $(\mathrm{P}<0.001)$ and remained

\footnotetext{
* Correspondence: chris.tyler@roehampton.ac.uk

Sports and Exercise Science Research Centre, Departemnt of Life Sciences, University of Roehampton, London, UK
}

\section{Discussion}

Cooling had no physiological effect on $\mathrm{T}_{\mathrm{re}}$ during hyperthermia trials. HOT appeared to show the greatest decline in voluntary force and was associated with a greater decline in CAR and normalised EMG in comparison to $\mathrm{CON}$. The higher force output for $\mathrm{HOT}_{\text {cooling }}$ may be explained by improved neural drive of the central nervous system to voluntarily activated muscles. 


\section{Conclusion}

Localised head and neck cooling improves neuromuscular function of the knee extensors during a sustained MVC under hyperthermic conditions.

Published: 14 September 2015

\section{References}

1. Nybo L, Nielsen B: Hyperthermia and central fatigue during prolonged exercise in humans. Journal of Applied Physiology 2001, 91:1055-1060.

2. Racinais S: Hot ambient conditions shift the force/EMG relationship. Springerplus 2013, 2:317.

3. Tyler $C$, Sunderland $C$ : Cooling the neck region during exercise in the heat. Journal of Athletic Training 2011, 46(1):61-68.

doi:10.1186/2046-7648-4-S1-A3

Cite this article as: Gordon et al:: The effect of hyperthermia with localised head and neck cooling on neuromuscular function. Extreme Physiology \& Medicine 2015 4(Suppl 1):A3.

Submit your next manuscript to BioMed Central and take full advantage of:

- Convenient online submission

- Thorough peer review

- No space constraints or color figure charges

- Immediate publication on acceptance

- Inclusion in PubMed, CAS, Scopus and Google Scholar

- Research which is freely available for redistribution

Submit your manuscript at www.biomedcentral.com/submit 